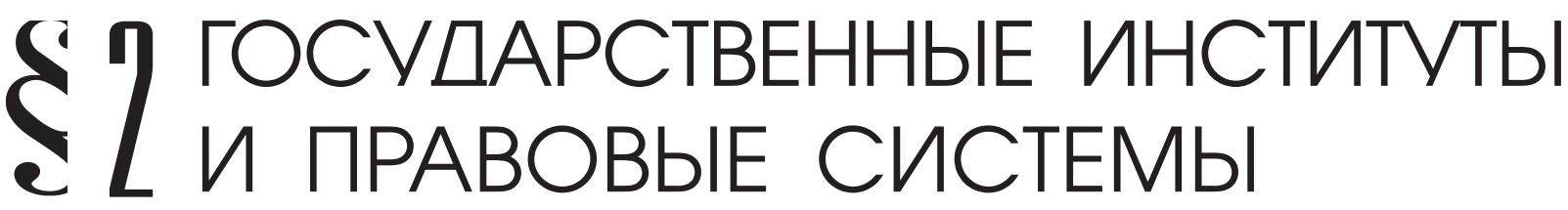

Жанузакова Л.Т.

\section{ПОЛНОМОЧИЯ ПРЕЗИДЕНТА РЕСПУБЛИКИ КАЗАХСТАН В ЗАКОНОДАТЕЛЬНОЙ СФЕРЕ}

\begin{abstract}
Аннотация: В статье рассмотрены право законодательной и конституционной инициативы Президента Республики Казахстан, право подписывать законы, принятые Парламентом, и вносить на них возражения (право отлагательного вето), его законодательные полномочия в случаях, закрепленных Конституцией, право давать законодательные поручения Правительству. Проанализированы особенности института контрасигнатуры в законодательстве республики в отношении законов, принятых Парламентом и подписываемых Президентом, указов главы государства, издаваемых по иниииативе Правительства, а также другие средства влияния главы государства на законодательный процесс. Методологию исследования составили общие и частные методы научного познания: системного анализа, формально-юридический, сравнительно-правовой и др. Отмечаются неточности в регулировании права законодательной инициативы Президента, как права вносить проекты законодательных актов в Мажилис Парламента. Введение понятия «законодательный акт» предоставляет ему вносить в парламент не только проекты законов, но и постановлений Парламента и его Палат, являющихся, по сути, подзаконными актами. Тем самым происходит вторжение в компетенцию высшего представительного органа по организачии своей деятельности. Президент республики - единственный субъект, который может реализовать право конституционной инициативы непосредственно: путем внесения проекта поправок в Конституцию в Парламент или на республиканский референдум. Парламент и правительство это право осуществляют косвенно: через Президента. Парадоксальным является отсутствие в числе инициаторов граждан, которые принимали Конституцию на референдуме. Поднимается вопрос о предоставлении им такого права. Изучение полномочий Президента по изданию актов законодательного характера показало, что необходимость в сохранении данного института отпала, в связи с формированием профессионального парламента, расширением его полномочий, наличием у главы государства права законодательной инициативы и других средств влияния на законодательный процесс. Внесены рекомендации по совершенствованию конституиионного законодательства.
\end{abstract}

Ключевые слова: Вето, делегирование, закон, законодательная инициатива,, законодательный акт, полномочия, парламент, президент, референдум, конституиия.

Abstract: This article explores the right in the legislative and constitutional initiative of the President of the Republic of Kazakhstan, the right to sign laws passed by the Parliament and object to them (the right to veto), president's legislative authority in the cases established by the constitutions, and the right to give legislative orders to the Government. Analysis is conducted on the institution of countersignature in the legislation of the Republic regarding laws passed by the Parliament and signed by the President, presidential decrees issued by the initiative of the Government, as well as other means of influence upon the legislative process by the head of state. Introduction of the concept of "legislative act" allows him to introduce into Parliament not only legislative bills, but also Parliamentary and Chambers decrees that are in fact by-laws. This is in essence an infringement upon the competency of the highest representative branch on organization of its activity. The President of the republic is the only subject who can directly realize the right of the constitutional initiative: by introduction of an amendment bill into the Constitution in the Parliament or at the republic referendum. The Parliament and the Government exercise this right indirectly - through the President. Study of the President's authority with regards to passing legislative acts revealed that the need for preserving this institution is no longer necessary, due to formation of professional Parliament, expansion of its authority, the right of the head of state to introduce legislative initiative, and other means of influencing the legislative process. The author makes recommendations on improving the Constitutional law.

Keywords: Parliament, authority, legislative act, legislative initiative, law, delegation, veto, President, referendum, Constitution. 
K онституция Республики Казахстан закрепила статус Президента как главы государства, его высшего должностного лица, определяющего основные направления внутренней и внешней политики государства [1]. Для реализации этой задачи он наделен самыми разными полномочиями, в том числе в законодательной сфере. Конституция и Конституционный закон от 26 декабря 1995 г. «О Президенте Республики Казахстан» [2] возлагают на Президента в этой связи следующие полномочия:

- право законодательной инициативы;

- право подписания законов, принятых Парламентом, и внесения на них возражений (право вето);

- право конституционной инициативы;

- право принятия законов в случае, предусмотренном Конституцией;

- право издания указов, имеющих силу закона;

- право дачи законодательных поручений Правительству.

Рассмотрим эти полномочия подробнее.

Право законодательной инициативы означает право внесения законопроектов в Парламент, в частности, в Мажилис (нижнюю Палату) Парламента. Это полномочие Президент получил в результате конституционной реформы 2007 г.

Термин «законодательная инициатива» по-разному трактуется в юридической литературе. Одни авторы понимают его достаточно широко, как внесение законопроекта или законодательного предложения в парламент [3, с.91-92; 4, с.179; 5, с.217]. Другие трактуют его узко, только как внесение проекта закона [6, с.568; 7, с.439].

Данное понятие достаточно неоднозначно формулируется в законодательстве. В соответствии с п.1 ст.15 Конституционного закона РК от 18 октября 1995 г. «О Парламенте Республики Казахстан и статусе его депутатов» «Законодательной инициативой является официальное внесение субъектом права законодательной инициативы текста проекта закона или иного законодательного акта Парламента, обязательного к рассмотрению Парламентом» [8]. Согласно Правилам реализации законодательной инициативы Президента Республики Казахстан, утвержденным Указом Президента РК от 21 сентября 2007 г. № 413, законодательной инициативой Президента «является официальное внесение Президентом Республики Казахстан своим специальным посланием на рассмотрение Мажилиса Парламента Республики Казахстан проекта законодательного акта Республики Казахстан» [9].
Таким образом, в законодательстве республики данный термин трактуется несколько иначе, чем оба подхода в юридической литературе, поскольку имеются в виду не только законы, но и постановления Парламента страны. При этом само решение о внесении проекта законодательного акта в Мажилис оформляется специальным посланием. Оно представляет собой официальное письмо Президента Республики Казахстан, посредством которого проект законодательного акта вносится в Мажилис Парламента, и которое должно содержать наименование проекта законодательного акта и обоснование его принятия. Право законодательной инициативы осуществляется в формах: внесения проектов законодательных актов РК; внесения проектов об изменениях, дополнениях и признании утратившими силу законодательных актов.

Однако де-факто законодательная инициатива Президента осуществляется путем внесения лишь проектов законов. То есть предложений о принятии нормативных постановлений Парламента со стороны главы государства обычно не исходит. По крайней мере, прецедентов не было. Связано это, на наш взгляд, в первую очередь, некорректным употреблением понятия «законодательный акт», которое по совершенно неясным причинам было введено в правовой оборот и фактически объединило в себе не только разные виды законов и актов, имеющих силу закона, но и постановления Парламента и его Палат - Сената и Мажилиса, то есть фактически подзаконные акты. При этом ни в Конституции, ни в Конституционном законе о Парламенте, ни в Законе «О нормативных правовых актах» не уточняется, что речь идет именно о нормативных постановлениях. Ведь постановления органа законодательной власти могут носить и индивидуальный характер, приниматься по вопросам его компетенции, например, по досрочному прекращению полномочий депутатов. Безусловно, Конституция и конституционный закон подразумевают нормативные постановления, однако четко это не оговаривают.

Можно отметить и разные подходы к данному понятию в упомянутых актах. Если Конституция, Конституционный закон «О Парламенте Республики Казахстан и статусе его депутатов» к законодательным актам относят постановления Парламента и его Палат, то Правила реализации законодательной инициативы Президента РК - лишь нормативные постановления Парламента.

Нормативные постановления Парламента и его Палат - это нормативные правовые акты подзаконного характера, которые принимаются по вопросам его компетенции и в иерархии нормативных правовых 
актов занимают место ниже законов, что прямо закреплено и п.7 ст.62 Конституции РК («Постановления Парламента и его Палат не должны противоречить законам») и в ст.4 Закона РК «О нормативных правовых актах» [10].

Анализируя разные законы, можно увидеть, что понятия «закон» и «законодательный акт» употребляются равнозначно. Между тем, на нормативные постановления Парламента и его Палат не распространяется порядок их обязательного подписания главой государства, они имеют более простую структуру по сравнению с законами, не могут приниматься по вопросам, обозначенным п.3 ст.61 Конституции РК, первичное правовое регулирование которых осуществляется законами и т.д.

В этой связи логично встает вопрос: если Президент, обладая правом законодательной инициативы в таком широком смысле, вносит на рассмотрение Парламента или его Палат, проект нормативного постановления, то не вторгается ли он тем самым в их компетенцию, в их право самостоятельно решать вопросы своей деятельности, не требующие регулирования в виде законов? Например, такими постановлениями были утверждены регламенты Парламента, Сената и Мажилиса.

Полагаем использование данного термина возможно только в юридической теории, объединяя в его содержание различные виды законов и актов, имеющих силу закона. Употребление же его в законодательстве является некорректным, поскольку вводит в заблуждение не только правоприменителей, но и физических и юридических лиц.

Следующее полномочие Президента в законодательной сфере - право подписания законов, принятых Парламентом, и внесения на них возражений (право вето). В соответствии с пп.2) ст.44 Конституции РК и пп.8) ст.9 Конституционного закона «О Президенте Республики Казахстан» Президент подписывает представленный Сенатом Парламента закон в течение одного месяца, обнародует закон либо возвращает закон или отдельные его статьи для повторного обсуждения и голосования; в течение одного месяца подписывает закон, если Парламент подтвердит ранее принятое решение с соблюдением требований, установленных пп.2) п.2 ст.54 Конституции.

Право подписания законов и их обнародования - традиционное полномочие главы государства. Оно означает его согласие с принятым парламентом законом и придание ему окончательной юридической силы, дача разрешения на его официальную публикацию. При этом конституционные поправки от 21 мая 2007 г. увеличили максимальный срок, отведенный
Президенту для подписания, с 15 рабочих дней до одного месяца (календарного). Это было обусловлено увеличением количества законов, принимаемых Парламентом, а также усложнением задач и функций самого Президента.

Президент обладает правом внесения возражений на закон, то есть правом вето. Причем оно распространяется только на законы, принятые Парламентом, но не касается законов, принятых на республиканском референдуме. Вето главы государства является отлагательным, оно может быть преодолено органом законодательной власти. Преодоление вето осуществляется квалифицированным большинством голосов: в отношении простых законов - не менее чем двумя третями голосов от общего числа депутатов каждой из Палат, в отношении конституционных законов - не менее чем тремя четвертями голосов от общего числа депутатов каждой из Палат. В этом случае Президент обязан подписать закон, но срок для подписания конституционной реформой 2007 г. также увеличен с семи рабочих дней до месяца, очевидно, по тем же мотивам.

Как отмечает В.А. Малиновский, право отлагательного вето Президента непосредственно связано с его статусом гаранта соблюдения Конституции и законов Казахстана. Являясь высшим должностным лицом страны, на котором лежит ответственность за качественную реализацию законов, он «свое отношение к конкретному акту может объяснить не только одним формально-юридическим основанием, но и какими-то иными экстраординарными обстоятельствами» [11, с.307].

Президентское вето является также «эффективным механизмом контроля законопроектов, позволяет преградить путь некачественным, дефектным законодательным актам» [12, с.173], «свидетельствует о качестве взаимодействия разных ветвей власти», выступает необходимым элементом системы сдержек и противовесов, при помощи которого реализуется принцип разделения властей [13, с.197].

За 20 лет работы Парламента Президент внес 19 возражений на законы, принятые Парламентом (по Земельному кодексу, законам «Об общественных объединениях», «О жилищных отношениях» и др.).

Интересные последствия наступают в случае непреодоления возражений Президента хотя бы одной из Палат: закон считается непринятым или принятым в редакции, предложенной Президентом. Иными словами, следствием вето может стать не вступление в силу закона, что является закономерным итогом отсутствия консенсуса у самих депутатов. Другой альтернативой является принятие закона в редакции, 
предложенной Президентом. В данном случае это, по сути, компромисс, который глава государства предлагает Парламенту, чтобы законопроект все-таки вступил в силу.

Следует сказать, что у высшего должностного лица страны имеются в этом отношении и другие полномочия, косвенно влияющие на его компетенцию в законодательной сфере. Это его право вносить представление в Конституционный Совет с ходатайством о проверке на соответствие Конституции законов, принятых Парламентом (п.1 ст.72 Конституции РК), которое он осуществляет до подписания закона. И позиция Конституционного Совета о конституционности закона прямо влияет на принятие главой государства решения о подписании закона.

Право конституционной инициативы - это право высшего должностного лица страны вносить проекты Конституции РК на республиканский референдум, проекты изменений и дополнений в Конституцию на республиканский референдум или в Парламент РК. Причем официальным инициатором изменений в Конституцию может быть сам Президент, а также Парламент и Правительство. Что касается граждан PК, то они в количестве не менее чем двести тысяч, в количественном отношении в равной мере представляющих все области, столицу Республики и города республиканского значения, могут быть инициаторами проведения республиканского референдума по другим вопросам, но только не по поправкам в Конституцию.

Некоторые авторы рассматривают данное право главы государства как одну из форм законодательной инициативы [14, с.352].

Полагаем, что хотя Конституция также является законом, право конституционной инициативы все же не может считаться формой законодательной инициативы. Во-первых, сама Конституция строго очерчивает субъектов законодательной и конституционной инициативы. В первом случае - это Президент, Правительство и депутаты Парламента. Во втором случае таким правом обладают Президент, Правительство и Парламент как орган, но не отдельные депутаты. При этом право инициировать изменения и дополнения в Основной Закон страны последние два субъекта могут не непосредственно, внося соответствующий проект в высший представительный орган или на республиканский референдум, а только через Президента. Именно он принимает решение отправить проект на референдум или в Парламент либо отклонить данное предложение. Иными словами, право конституционной инициативы главы государства является его дискреционным полномочием, а со- ответствующие права Парламента и Правительствапроизводными от его права. Правда, конституционной реформой 1998 г. Парламент получил право внести изменения и дополнения в Конституцию большинством в четыре пятых голосов депутатов каждой из Палат (против большинства в три четверти голосов в обычном порядке) в случае, если его предложение о внесении поправок в Конституцию на республиканский референдум было отклонено Президентом. Но и в этом случае последнее слово остается за главой государства. Он либо подписывает закон, либо выносит этот вопрос на референдум.

Во-вторых, согласно Конституции право законодательной инициативы реализуется в Мажилисе Парламента, тогда как право конституционной инициативы также и на республиканском референдуме. В этой связи возникает вопрос: а если депутаты или Правительство инициируют принятие закона на референдуме, это является законодательной инициативой? В данном случае это уже право инициативы назначения всенародного голосования, которое принадлежит Президенту, Правительству, Парламенту, а также не менее чем двумстам тысяч граждан, в количественном отношении в равной мере представляющим все области, столицу и город республиканского значения. Однако, как указывалось выше, граждане в отношении поправок в Конституцию таким правом не обладают.

Представляется неприемлемой ситуация, когда народ, как единственный источник государственной власти, как единственный полномочный субъект принятия Конституции (в компетенцию Парламента этот вопрос не входит), не может быть инициатором ее изменения. Следовало бы это право вернуть народу и закрепить его в главном законе страны.

Что касается других субъектов, кроме перечисленных, то все они, включая граждан в любом количестве, могут действовать неофициально: внося соответствующие предложения официальным субъектам конституционной инициативы.

В отношении разработки и принятия новой Конституции ни сам главный закон страны, ни Конституционный закон от 2 ноября 1995 г. «О республиканском референдуме» не оговаривают инициаторов. Поэтому можно предположить, что граждане в этом случае могут выходить с соответствующей инициативой к Президенту. Но, так или иначе, следовало бы этот пробел в законодательстве восполнить.

Президент имеет право обращаться к Парламенту с инициативой о делегировании ему законодательных полномочий. Парламент на совместном заседании Палат решает этот вопрос на совместном заседании 
Сената и Мажилиса и двумя третями голосов от общего числа депутатов каждой из Палат может делегировать ему право принятия законов на срок, не превышающий одного года.

Конституционный Совет в своем нормативном постановлении от 26 июня 2008 г. № 5 дал официальное толкование п. 2 ст.45и пп.3) и 4) ст.53 Конституции. В своем решении Совет исходил из признания того факта, что временная передача парламентом своих законодательных полномочий главе государства либо правительству (институт делегированного законодательства) распространена в зарубежных странах со смешанной либо парламентарной формами правления. Она является одним из средств выхода из сложных ситуаций в общественном развитии через ускоренное совершенствование законодательства с соблюдением установленных требований. К таковым, - по мнению Совета, - могут быть отнесены особые процедуры принятия закона о передаче полномочий, сроки делегирования, предметы (сферы) законодательного регулирования и другие условия.

Парламент РК вправе делегировать Президенту республики полномочия по изданию законов: в мирное время в соответствии с ппп.3) ст.53 Конституции; в военное время в соответствии с п. 2 ст.45 и пп.4) ст.53 Конституции.

На основании указанных статей Конституции Президент республики вправе осуществлять делегированные Парламентом полномочия по изданию, приостановлению действия и отмене законов, внесению в законы изменений и дополнений.

В постановлении Совета раскрыты также пределы осуществления Президентом делегированных законодательных полномочий: в мирное время - принятие Парламентом на совместном заседании палат двумя третями голосов от общего числа депутатов каждой из палат по инициативе Президента республики закона о временном делегировании главе государства законодательных полномочий на срок, не превышающий одного года; в военное время - принятие Парламентом на совместном заседании палат решения об объявлении состояния войны [15].

Если обратиться к истории первых лет независимости, то прецедент издания Президентом республики актов законодательного характера уже был. Верховный Совет РК 12 созыва перед своим самороспуском 10 декабря 1993 г. принял Закон «О временном делегировании Президенту Республики Казахстан и главам местных администраций дополнительных полномочий», которым предоставил право высшему должностному лицу принимать акты, имеющие силу закона, до начала работы Верховного
Совета нового созыва. Не вдаваясь в подробности обстоятельств принятия и условий действия данного Закона, лишь отметим, что в 1995-1996 г.г. Президент, воспользовавшись данным правом, «взяв на себя ответственность, провел конституционную реформу и ряд крупных экономических преобразований, включая введение частной собственности на землю», начал «активно заполнять сложившийся правовой вакуум». У него появилась «эффективная возможность существенно обновить законодательную базу в условиях отсутствия оппонента в лице высшего представительного органа» [16, с.25].

В частности, за период с марта 1995 г. по январь 1996 г. Президент издал 134 указа, имеющих силу конституционного или обычного закона. Многие из них продолжают действовать и сегодня, хотя их форма изменилась. Теперь это конституционные или обычные законы, поскольку в эти акты вносились изменения и дополнения Парламентом, избранным на основе Конституции 1995 г. Некоторые указы Президента, имеющие силу закона, были отменены в связи с разработкой и принятием высшим представительным органом собственных законов.

Н наш взгляд, данная норма в Конституции была оправданна в период, когда принималась Конституция. Во-первых, нестабильная социальноэкономическая и политическая обстановка того времени порождала возможность кризисных моментов в отношениях между органами власти. Во-вторых, институт профессионального парламента только начал складываться, отсутствовал необходимый опыт законотворческой практики, не хватало квалифицированных специалистов в этой сфере. Поэтому была необходимость для оперативного принятия законов в этих условиях. В современный период с уже наработанной законодательной практикой, с более профессиональным депутатским корпусом и аппаратом Палат Парламента, с предоставлением Президенту права законодательной инициативы в указанном полномочии главы государства нет острой необходимости. У него есть и другие каналы воздействия на законодательный процесс. Наверное, поэтому с момента принятия Конституции 1995 г. он так ни разу не воспользовался данным правом.

В соответствии с п. 2 ст.61 Конституции Президент Республики имеет право определять приоритетность рассмотрения проектов законов, а также объявлять рассмотрение проекта закона срочным, означающее, что Парламент должен рассмотреть данный проект в течение месяца со дня его внесения. При неисполнении Парламентом настоящего требования Президент Республики вправе издать указ, 
имеющий силу закона, который действует до принятия Парламентом нового закона в установленном Конституцией порядке.

Порядок определения приоритетности рассмотрения законопроектов закреплен Правилами определения приоритетности рассмотрения проектов законов, а также объявления рассмотрения проекта закона срочным, утвержденными указом Президента от 29 апреля 2003 г. № 1074 [17].

Это еще одно его полномочие по изданию актов законодательного характера. Оно является также средством оперативного решения вопроса, связанного с принятием закона. Глава государства может повлиять на очередность рассмотрения и принятия законопроектов, которые жизненно необходимы в той или иной общественно-политической или социальноэкономической ситуации. Парламенту в случае объявления законопроекта срочным дается всего лишь месяц, тогда как в обычных условиях принятие закона может затянуться на несколько месяцев и даже лет.

Однако эта норма несколько размыто закреплена в Конституции, где говорится о рассмотрении проекта в течение месяца, хотя, исходя из последствий неисполнения этого требования, можно смело утверждать, что здесь подразумевается и принятие закона. В этой связи целесообразно было бы соответствующим субъектам обратиться в Конституционный Совет РК с ходатайством об официальном толковании п.2 ст.61 Конституции в части разъяснения термина «рассмотрение».

Можно отметить, что прецедентов издания указов, имеющих силу закона, на основании данной нормы Конституции также не было.

Следующее полномочие высшего должностного лица - право дачи законодательных поручений Правительству. По сути, здесь объединились два полномочия Президента: поручение Правительству внесение законопроекта в Мажилис Парламента и дача ему законодательных поручений (пп.7) и 14) ст.10 Конституционного закона «О Президенте Республики Казахстан»). В Конституции нашло отражение только первое полномочие.

Есть точка зрения, согласно которой право Президента поручать Правительству внесение законопроекта в Мажилис и давать ему законодательные поручения - форма реализации законодательной инициативы [14, с.352].

Понятие законодательной инициативы достаточно четко сформулировано в Конституционном законе «О Парламенте Республики Казахстан и статусе его депутатов» и не может трактоваться слишком широко. Данные полномочия Президента, хотя и направ- лены на реализацию законодательной инициативы Правительства, но все же являются самостоятельными полномочиями высшего должностного лица по участию в законодательном процессе.

С одной стороны, поручение Правительству внести законопроект в Мажилис Парламента подразумевает и его разработку, то есть охватывает и второе полномочие. С другой стороны, можно предположить, что законопроект был разработан Администрацией Президента или другим субъектом, а Правительству поручается внести его на рассмотрение Парламента. В то же время у Президента есть собственное право законодательной инициативы, поэтому отсутствует логика в добровольном отказе от собственного права в такой ситуации. Если же законопроект разработан другим субъектом, а Президент поручает высшему исполнительному органу внести его в Мажилис, то последний включается в процесс разработки и в любом случае будет дорабатывать законопроект, прежде чем внести в Парламент.

Что касается дачи законодательного поручения Правительству, то оно может касаться как проектов, разрабатываемых самим Правительством и вносимых им в Парламент, так и разработки законопроектов, которые будут вноситься в порядке реализации законодательной инициативы Президента. В этом случае данное полномочие не совпадает полностью с первым.

В то же время взаимосвязь этих полномочий очевидна, и непонятна позиция законодателя, который развел их в разные пункты ст.9 Конституционного закона о Президенте. Представляется, что более правильным было бы объединить их в одной норме, изложив ее следующим образом: «дает получения Правительству о разработке проекта закона и внесении его в Мажилис Парламента либо Президенту в порядке реализации законодательной инициативы Президента».

Эти полномочия непосредственно вытекают также из статуса Президента как высшего должностного лица, определяющего основные направления внутренней и внешней политики государства. В частности, он определяет основные направления правовой политики страны, частью которой является законодательная политика.

Так, указом Президента РК от 24 августа 2009 г. № 858 утверждена Концепция правовой политики Республики Казахстан на период с 2010 до 2020 года [18]. Она стала основой для разработки соответствующих программ в области правовой политики государства, перспективных и ежегодных планов законопроектных работ Правительства, проектов нормативных правовых актов Республики. Многие ее положения на сегодня претворены, в том числе в виде соответствующих законов. 
Еще одним примером такого рода можно назвать президентскую программу 2015 г. «План нации - сто конкретных шагов» [19]. Данный документ направлен на реализацию пяти институциональных реформ (по формированию профессионального государственного аппарата, обеспечению верховенства закона и т.д.) и содержит в числе прочих мер разработку и принятие целого ряда законов.

На высший исполнительный орган возлагается реализация правовой политики, согласование с Главой государства плана законопроектных работ Правительства (пп.14) ст.9, п.2 ст.12 Конституционного закона «О Правительстве Республики Казахстан» [20].

Непосредственное влияние на законодательный процесс оказывают ежегодные послания Президента народу Казахстана, в котором он озвучивает, в том числе, основные задачи по законодательному урегулированию тех или иных вопросов.

Конституцией Республики 1995 г. (п.3 ст.45) введен институт контрасигнатуры, который подразумевает предварительное скрепление актов главы государства подписью главы или члена правительства, на которых возлагается юридическая ответственность за законность данных актов. Данный институт существует обычно в странах с парламентской формой правления, где глава государства слабый и не имеет практически властных полномочий. Фактически функции Президента или монарха как главы государства выполняет Премьер-Министр. Акты первого принимаются по инициативе Правительства. Поэтому и ответственность несет его глава или министр.

По мнению Н.А. Филипповой, «и конституционная практика, и правосознание Казахстана возрождают мифологию «переноса ответственности», характерную для возникновения института контрасигнатуры в начале XIX в. в европейских монархиях. Содержание анализируемых норм может быть понято через сопоставление их с административным типом контрасигнатуры - с присущим ему отсутствием парламентской ответственности правительства, доминированием предварительных форм согласования актов главы государства, отсутствием процессуальных ограничений в реализации полномочий государя и конституционных гарантий автономии правительства в его взаимоотношениях с главой государства» [21, с.277].

В Казахстане этот институт нашел закрепление в следующей форме. Акты Парламента, подписываемые
Президентом Республики, а также акты Президента, издаваемые по инициативе Правительства, предварительно скрепляются соответственно подписью Председателя каждой из Палат Парламента либо Премьер-Министра, на которых возлагается юридическая ответственность за законность данных актов.

В первом случае речь идет о законах, принятых Парламентом. Трудно понять, чем руководствовался законодатель, когда вносил данную норму. Понятно, что принятие законов - собственная прерогатива Парламента. Тем более что пока законопроект проходит в его стенах, в него вносятся многочисленные поправки. И даже если он исходит от Президента, это не значит, что законопроект будет принят абсолютно в той редакции, которую внес глава государства. Поэтому оговаривать, что он не несет ответственности в данном случае, нет необходимости. Но и возлагать ответственность на председателей Палат тоже представляется излишним и неправильным. Председатели Сената и Мажилиса не могут запретить депутатам вносить изменения и дополнения, а тем более при принятии законопроекта они могут быть на стороне меньшинства. И тогда почему они должны нести юридическую ответственность за законность таких актов?

На наш взгляд, эта норма должна быть исключена из Конституции, учитывая, что средств контроля за законностью самих законов предостаточно (рассмотрение в Конституционном Совете, право возражений Президента).

Что касается актов Президента, издаваемых по инициативе Правительства, то возложение юридической ответственности на Премьер-Министра еще можно в какой-то степени оправдать, т.к. в последние годы происходит трансформация президентской республики в президентско-парламентскую, усиление самостоятельности Правительства в решении многих вопросов. Но есть ли необходимость в этом институте - другой вопрос. По крайней мере, за более чем 20 лет прецедентов действия данной нормы также не было. Поэтому ее целесообразно исключить.

Таким образом, полномочия Президента Республики в законодательной сфере позволяют ему в достаточной степени влиять на законодательный процесс в Парламенте, обеспечивать принятие им качественных законов, а также в необходимых случаях брать на себя ответственность по оперативному изданию актов законодательного характера.

\section{Библиография:}

1. Конституция Республики Казахстан. Принята 30 августа 1995 г. на республиканском референдуме. С изменениями и дополнениями, внесенными законами РК от 7 октября 1998 г., от 21 мая 2007 г. и от 2 февраля 2011 г. - Ведомости Парламента РК. - 1996. - № 4. - Ст. 217; 1998. - № 20. - Ст.245; 2007. - № 10. - Ст.68; 2011. - № 3. - Ст.29 
2. Конституционный закон от 26 декабря 1995 г. «О Президенте Республики Казахстан» //Ведомости Верховного Совета РК. - 1995. - № 24. - Ст.172

3. Иванец Г. И., Калининский И. В., Червонюк В. И. Законодательная инициатива // Конституционное право России: Энциклопедический словарь / Под общ. ред. проф. В. И. Червонюка. - М.: Юридическая литература. $2002 .-432$ с.

4. Мухамеджанов Э. Б. Конституционное (государственное) право зарубежных стран. - Алматы: Жеты Жаргы, 2014. $-356 \mathrm{c}$.

5. Караев А. А. Конституционное право Республики Казахстан (Учебно-методическое пособие). - Алматы, 2015. - 304 с.

6. Баглай М. В. Конституционное право Российской Федерации : учеб. для вузов. - 6-е изд., изм. и доп. - М.: Норма. 2007. - $784 \mathrm{c}$.

7. Конституция Российской Федерации: Проблемный комментарий /Отв. ред. В. А. Четвернин. - М., 1997. - 702 с.

8. Конституционный закон РК от 18 октября 1995 г. «О Парламенте Республики Казахстан и статусе его депутатов» // Ведомости Верховного Совета РК. - 1995. - № 21. - Ст.124

9. Правила реализации законодательной инициативы Президента Республики Казахстан. Утверждены Указом Президента РК от 21 сентября 2007 г. № 413 //Собрание актов Президента и Правительства РК. - 2007. - № 34. - Ст.372

10. Закон РК от 24 марта 1998 г. «О нормативных правовых актах» //Ведомости Парламента РК. - 1998. - № 2-3. - Ст.25

11. Малиновский В. А. Лидер: президентская власть в Казахстане на рубеже эпох.: Монография. - Астана: ТОО «Издательство «Норма-К», 2012. - 528 с.

12. Ширяев Ю. Е. Вето Президента России в федеральном законодательном процессе //Вестник Санкт-Петербургского университета МВД России. - 2006. - № 2. - С.168-174.

13. Гудиева М.С. Право вето Президента в развитии демократии //Перспективы интеграции науки и практики. - 2014. - № 1. - С.196-197

14. Конституция Республики Казахстан. Научно-практический комментарий. - Алматы: Раритет, 2015. - 536 с.

15. Нормативное постановление Конституционного Совета РК от 26 июня 2008 г. № 5 «Об официальном толковании пункта 2 статьи 45, подпунктов 3) и 4) статьи 53 Конституции Республики Казахстан» //Казахстанская правда. 2008. - 21 августа

16. Сафарова Т. С. Президент и законодательная власть. Автореф. дисс...уч. степ. канд. юр. наук. - Алматы, 1996. - 28 с.

17. Правила определения приоритетности рассмотрения проектов законов, а также объявления рассмотрения проекта закона срочным. Утверждены указом Президента от 29 апреля 2003 г. № 1074 // Собрание актов Президента и Правительства РК. - 2003. - № 17. - Ст.169

18. Указ Президента РК от 24 августа 2009 г. № 858 «О Концепции правовой политики Республики Казахстан на период с 2010 до 2020 года» //Казахстанская правда. - 2009. - 27 августа

19. Программа Президента РК от 20 мая 2015 г. «План нации - сто конкретных шагов» //Казахстанская правда. - 2015. -20 мая

20. Конституционный закон РК от 18 декабря 1995 г. «О Правительстве Республики Казахстан» //Ведомости Верховного Совета РК. - 1995. - № 23. - Ст.145

21. Филиппова Н. А. Институт контрасигнатуры и конституционные гарантии автономии правительств в постсоветских государствах //Политическая экспертиза: ПОЛИТЭКС, 2006. Том 2. - № 2. - С. 268-278

\section{References (transliterated):}

1. Ivanets G. I., Kalininskii I. V., Chervonyuk V. I. Zakonodatel'naya initsiativa // Konstitutsionnoe pravo Rossii: Entsiklopedicheskii slovar' / Pod obshch. red. prof. V. I. Chervonyuka. - M.: Yuridicheskaya literatura. 2002. - $432 \mathrm{~s}$.

2. Mukhamedzhanov E. B. Konstitutsionnoe (gosudarstvennoe) pravo zarubezhnykh stran. - Almaty: Zhety Zhargy, 2014. - $356 \mathrm{~s}$.

3. Karaev A. A. Konstitutsionnoe pravo Respubliki Kazakhstan (Uchebno-metodicheskoe posobie). - Almaty, 2015 . - 304 s.

4. Baglai M. V. Konstitutsionnoe pravo Rossiiskoi Federatsii : ucheb. dlya vuzov. -6-e izd., izm. i dop. - M.: Norma. 2007 . - 784 s.

5. Malinovskii V. A. Lider: prezidentskaya vlast' v Kazakhstane na rubezhe epokh.: Monografiya. - Astana: TOO «Izdatel'stvo «Norma-K», 2012. - $528 \mathrm{~s}$.

6. Shiryaev Yu. E. Veto Prezidenta Rossii v federal'nom zakonodatel'nom protsesse //Vestnik Sankt-Peterburgskogo universiteta MVD Rossii. - 2006. - № 2. - S.168-174.

7. Gudieva M.S. Pravo veto Prezidenta v razvitii demokratii //Perspektivy integratsii nauki i praktiki. - 2014. - № 1. - S.196-197

8. Safarova T. S. Prezident i zakonodatel'naya vlast'. Avtoref. diss...uch. step. kand. yur. nauk. - Almaty, 1996. - 28 s.

9. Filippova N. A. Institut kontrasignatury i konstitutsionnye garantii avtonomii pravitel'stv v postsovetskikh gosudarstvakh // Politicheskaya ekspertiza: POLITEKS, 2006. Tom 2. - № 2. - S. 268-278 